\title{
The Attempt to Understand Puerperal Fever in the Eighteenth and Early Nineteenth Centuries: The Influence of Inflammation Theory
}

\author{
CHRISTINE HALLETT*
}

\begin{abstract}
Introduction
Puerperal fever was a devastating disease. It affected women within the first three days after childbirth and progressed rapidly, causing acute symptoms of severe abdominal pain, fever and debility. Although it had been recognized from as early as the time of the Hippocratic corpus that women in childbed were prone to fevers, the distinct name, "puerperal fever" appears in the historical record only in the early eighteenth century. ${ }^{1}$

The purpose of this paper is to trace some of the ideas within those medical treatises on puerperal fever which were published during the period from 1760 to 1850 . Previous historical writing, with the exception of Margaret DeLacy's overview of puerperal fever in eighteenth-century Britain, and George Lowis's paper considering the work of Alexander Gordon, has either focused on the innovations of the later nineteenth century or offered a broad overview of the subject which has tended to pass over the eighteenth and early nineteenth centuries with little comment, moving rapidly to the contributions of a later generation of physicians in the later nineteenth and twentieth centuries. ${ }^{2}$ Those contributions appeared to cast light on the infectious nature of puerperal fever. The disease is currently believed to be caused by a bacterial infection of the upper genital tract, in which the most common causative organism is the Beta haemolytic streptococcus, Lancefield Group A. ${ }^{3}$

Death and disease caused by childbirth were a commonplace of early modern life. Pre-eclampsia, ante-partum and post-partum haemorrhage and cephalopelvic disproportion were only a few of the complications which could affect women and children at this most

(C) Christine Hallett 2005

* Christine Hallett, PhD, School of Nursing, Midwifery and Health Visiting, Coupland 3 Building, The University of Manchester, Oxford Road, Manchester, M13 9PL, UK; e-mail:

Christine.Hallett@man.ac.uk

I would like to acknowledge the invaluable help and guidance of Professor Brian Pullan, who supervised the work on which this paper was based. I would also like to acknowledge the help of the two anonymous reviewers, who made important suggestions for improvements to the paper, and of Caroline Tonson-Rye.

${ }^{1}$ The debate about when this term first emerged is presented by Irvine Loudon,

The tragedy of childbed fever, Oxford University Press, 2000, p. 8.

${ }^{2}$ Margaret DeLacy, 'Puerperal fever in eighteenth-century Britain', Bull. Hist. Med., 1989, 63 (4): 521-56; George W Lowis, 'Epidemiology of puerperal fever: the contribution of Alexander Gordon', Med. Hist., 1993, 37: 399-410; Loudon, op. cit., note 1 above, passim. See also Stanley A Seligman, 'The lesser pestilence: non-epidemic puerperal fever', Med. Hist., 1991, 35: 89-102.

${ }^{3}$ Loudon, op. cit., note 1 above, pp. 1-13, 189-212; Group B streptococcus has also been implicated, see D I Lansing, W R Penman, and D J Davis, 'Puerperal fever and the Group B beta haemolytic streptococcus', Bull. Hist. Med., 1983, 57: 70-80; Seligman, op. cit., note 2 above, DeLacy, op. cit., note 2 above, pp. 526-9.
\end{abstract}




\section{Christine Hallett}

dangerous time. ${ }^{4}$ The Edinburgh physician William Campbell, in his treatise of 1822 , observed that the symptoms of puerperal fever could be complex and difficult to interpret. In the majority of patients the disease appeared on the third day, and commenced with rigor, headache and the "cold fit" followed by extreme heat, perspiration and thirst. Abdominal pain was an almost ubiquitous feature and this began as a mild symptom, becoming increasingly severe over the duration of the disease. This pain-which was accompanied by abdominal distension — was usually located in the hypogastric and iliac regions, and any apparent remission tended to be dangerous, indicating mortification. There was "great derangement of the vascular system", the pulse rising to as much as 140 beats per minute, and the patient tended to lie on her back and appear listless and indifferent. The tongue was usually white, although it could become dark and furred in the face of impending death. Respiration was difficult due to the abdominal pain and distension, and the patient was prone to nausea and vomiting. The early stages of the disease could be characterized by constipation, which, however, soon gave way to diarrhoea. Urination was usually painful and the urine was "high coloured and turbid". The production of milk was usually suppressed, but the flow of lochia tended to continue. A minority of sufferers experienced delirium and mania. ${ }^{5}$

It was not only the disturbing and extreme symptomatic presentation of puerperal fever that distressed practitioners, but also its intractable nature. ${ }^{6}$ Adding to the anxiety of

\footnotetext{
${ }^{4}$ Loudon, op. cit., note 1 above; idem, Death in childbirth: an international study of maternal care and maternal mortality, 1800-1950, London, Clarendon Press, 1992; idem, 'On maternal and infant mortality, 1900-1960', Soc. Hist. Med., 1991, 4 (1): 29-73.

See also, J S Lewis, In the family way: childbearing in the British aristocracy, 1760-1860, New Jersey, Rutgers University Press, 1986. For interesting comment, see also Angus McLaren, 'The pleasures of procreation: traditional and biomedical theories of conception', in W F Bynum and Roy Porter (eds), William Hunter and the eighteenth-century medical world, Cambridge University Press, 1985, pp. 323-41.

${ }^{5}$ William Campbell, A treatise on the epidemic puerperal fever, Edinburgh, Bell and Bradfute, 1822, pp. 26-52. Eighteenth- and early-nineteenth-century descriptions of the symptoms and course of puerperal fever were usually minute and detailed. William Campbell was born in Scotland. He practised man-midwifery in Edinburgh, and was physician to the Edinburgh Infirmary during the 1820s. For other descriptions of the symptoms and progress of puerperal fever, see Thomas Denman, Essays on the puerperal fever and puerperal convulsions, London, printed for J Walter, 1768, pp. 8-10. There is a much more detailed description in Denman's later edition: idem, Essays on the puerperal fever, 2nd ed., London, printed by J Cooper for J Walter, 1773, pp. 9-12; Henry Manning, A treatise on female diseases, London, printed for R Baldwin, 1771, pp. 390-3; Nathaniel Hulme, A treatise on the puerperal fever, London, printed for
}

T Cadell, 1772,pp. 1-19; William Butter, An account of puerperal fevers, London, T Payne, 1775, pp. 1-6; Charles White, A treatise on the management of pregnant and lying-in women, London, E and C Dilly, 1773, pp. 13-17; Philip Pitt Walsh, Practical observations on the puerperalfever London, for C Dilly (and others), 1787, pp. 1-10; John Clarke, An essay on the epidemic disease of lying-in women, London, J Johnson, 1788, pp. 12-22, 30-4; idem, Practical essays on the management of pregnancy and labour, London, J Johnson, 1793, pp. 123-35; Alexander Gordon, A treatise on the epidemic puerperal fever of Aberdeen, London, printed for G G and J Robinson, 1795, pp. 5-13; G E Mitchell, Inaugural essay, on the puerperal state offever, Philadelphia, printed by John $\mathrm{H}$ Oswald, 1805, pp. 11-13; John Armstrong, Facts and observations relative to the fever commonly called puerperal, London, Longman, Hurst, Rees, Orme and Brown, 1814, pp. 1-12; Robert Gooch, Account of some of the most important diseases peculiar to women, London, Murray, 1829, pp. 1-2; John Alexander, Medical commentaries on puerperal fever, London, Longman, 1836, pp. 9-10; A C Baudelocque, Treatise on puerperal peritonitis, transl. G S Bedford, New York, Elliot and Palmer for Collins and Hannay, 1831, pp. 154-79.

${ }^{6} \mathrm{See}$, for example, Campbell's discussion of the attempts of William Hunter to treat by various different methods: Campbell, op. cit., note 5 above, p. 14; on the symptoms and "character" of fevers more generally, see William Fordyce, A new inquiry into the causes, symptoms and cure of putrid and inflammatory fevers, 


\section{The Attempt to Understand Puerperal Fever}

physicians was the tendency of the disease to appear in "epidemic" form, in which the case fatality rate was high -70 to 80 per cent, as compared with 25 to 30 per cent in the sporadic form. ${ }^{7}$ John Clarke commented in his treatise of 1793 that the first useful account of a puerperal fever epidemic was the reference to an epidemic in the Paris Hôtel Dieu in 1745/6, which could be found in the Mémoires de l'Académie Royale des Sciences for the year $1746 .{ }^{8}$ In fact, it would appear that interest in the disease among British practitioners was first seriously aroused by what was probably the first British epidemic at the British Lyingin Hospital in $1760 .{ }^{9}$ According to Campbell, the term "puerperal fever" was first used by Edward Strother in his 1716 Criticon febrium. ${ }^{10}$

John Mackintosh, writing in the 1820s, commented that "there is not a corner in Britain where this formidable disease has not made many mourners", ${ }^{11}$ but observed that a number of particular epidemics had become famous as a result of having been recorded and then repeatedly described in eighteenth- and early-nineteenth-century treatises on the subject. Alongside the Paris epidemic of 1745/6 and the London epidemic of 1760/1, he cited the 1768 and 1770 epidemics in London and other parts of England; the prolonged epidemic in Aberdeen from 1789-92 recorded by Alexander Gordon; ${ }^{12}$ and the epidemics in Leeds and Sunderland described respectively by William Hey and John Armstrong. ${ }^{13}$ Case fatality rates had varied enormously. For example, it was reported that, during the epidemic at the Westminster Lying-in Hospital in 1770, out of sixty-three women delivered, nineteen contracted the disease and thirteen of these died. In the Aberdeen epidemic, out of seventy-seven patients with the disease, twenty-eight died. However, Mackintosh also

London, printed for T Cadell, J Murray and W Davenhill, 1777, pp. 12-14; For an example of a particularly intractable case, see Samuel Cusack, A brief notice of the disease popularly termed puerperal fever, Edinburgh (extracted from the Edinb. med. surg. J., no. 98), 1829, pp. 26-7.

${ }^{7}$ Loudon, op. cit., note 1 above, p. 190; Denman refers to puerperal fever as "very often fatal",

Denman, 1st ed., 1768, op. cit., note 5 above, p. 5 . See also Manning, op. cit. note 5 above.

${ }^{8}$ Clarke, Practical essays, op. cit., note 5 above, pp. 102-5. John Clarke was born in Wellingborough; he became a member of the Corporation of Surgeons and established a surgical practice in Chancery Lane. He lectured on midwifery at St Bartholomew's Hospital. He became MD in 1791 and Licentiate in Midwifery of the Royal College of Physicians in London in 1787. He was physician to the Lying-in Hospital in Store Street, and the Asylum for Female Orphans in the 1780s and 1790s.

${ }^{9}$ Seligman, op. cit., note 2 above, p. 89; DeLacy, op. cit., note 2 above, p. 521. For a list of puerperal fever epidemics, see August Hirsch, Handbook of geographical and historical pathology, transl. Charles Creighton, London, New Sydenham Society, 1885, vol. 2, pp. 422-4. See also, Fleetwood Churchill (ed.), Essays on puerperal fever and other diseases peculiar to women, London, printed for the Sydenham Society, 1849 , p. 6.

\footnotetext{
${ }^{10}$ Campbell, op. cit., note 5 above, pp. 8, 12-13. Campbell refers to works by M Malouin and Jean Astruc. Moore appears also to have consulted this text, but in its second edition of 1718: G Moore, An enquiry into the pathology, causes, and treatment of puerperal fever, London, S Highley, 1836, p. 5. Mention is also make of this text in Alexander, op. cit., note 5 above, p. 3. See also Michael Ryan, A manual on midwifery, London, printed for Longman etc., 1828, p. 319.

Loudon quotes the first edition of 1716 , op. cit., note 1 above, p. 15.

${ }^{11}$ John Mackintosh, A treatise on the disease termed puerperal fever, Edinburgh, W Blackwood, 1822 , p. 5. John Mackintosh was born in Scotland and obtained his MD from Edinburgh University. He practised man-midwifery in Edinburgh, and was physician to the Edinburgh Infirmary during the 1820 s.

${ }^{12}$ Gordon, op. cit., note 5 above. Gordon was practising as a man-midwife in Aberdeen at the time he wrote this treatise. He was also physician to the Aberdeen Dispensary.

${ }^{13}$ William Hey was practising as a man-midwife in Leeds during the second decade of the nineteenth century; John Armstrong was practising in Sunderland at around the same time. Both wrote treatises based on observations from their own practice: William Hey, $A$ treatise on the puerperal fever, illustrated by cases, which occurred in Leeds and its vicinity in the years 1809-1812, London, Longman, Hurst, Rees, Orme and Brown 1815; Armstrong, op. cit., note 5 above.
} 


\section{Christine Hallett}

observed that, during an epidemic in the Lying-in Ward of the Edinburgh Infirmary "many years ago", all who contracted the disease died. ${ }^{14}$ The wide variations in the reports of eighteenth- and nineteenth-century authors make it impossible for a modern researcher to reconstruct accurately the incidence, mortality or case fatality rates for this disease. ${ }^{15}$ It is, however, clear that it was greatly feared by both patients and medical men. Once a woman contracted it, all recognized that she was likely to die. Emotions around the issue of puerperal fever therefore ran high, and the discovery of its nature and cure was a priority for the medical men of this time. A reading of the medical treatises of the later eighteenth-century creates the impression that this period was one of unprecedented confusion in the study of fevers. ${ }^{16}$ Nowhere is this impression stronger than in the writings on puerperal fever.

Man-midwifery was an uncertain but increasingly fashionable and sometimes quite lucrative area of practice for physicians; it may, for this reason, have been a field in which ideas about theory and practice were particularly strongly contested. Midwifery, formerly the preserve of women, was receiving increasing attention from medical menboth physicians and surgeons - during the eighteenth century. Prominent within this area of practice were the surgeons, for whom midwifery was seen as a natural extension of their activities. Surgeons had traditionally been called in to difficult births by midwives, usually when there was a need to extract an already dead foetus from the womb in order to save a mother's life. During the eighteenth century, surgeons were increasingly finding ways to extend their practice into the area of normal childbirth. ${ }^{17}$ Men-midwives, although recognized by society as holding respectable positions and possessing expertise, found their status limited by the "hands-on" nature of their work. ${ }^{18}$ Nevertheless, within broader social terms, man-midwifery could be seen as a field of financial and career opportunity. ${ }^{19}$ These ambiguities and uncertainties within the status of men-midwives may have contributed to the intensity and competitiveness of the debates which can be found in their writings.

The second half of the eighteenth century saw increasingly determined attempts by surgeons to raise their status. The formation of the Company of Surgeons in 1745 and then of the Royal College of Surgeons of London in 1800 permitted them to present themselves as "pure surgeons", practising at a level higher than that of the surgeonapothecary. ${ }^{20}$ For this reason, surgeons were distancing themselves from man-midwifery, and élite men-midwives - particularly those who undertook some practice within lying-in

\footnotetext{
${ }^{14}$ Mackintosh, op. cit., note 11 above, pp. 1-5. Alexander refers to epidemics in Dublin in 1767, Edinburgh in 1773 and 1821-2, London in 1787-8, Leeds in 1809, Paris in 1829, Glasgow in 1819 and Manchester, where he himself was based, in 1828-9; Alexander, op. cit., note 5 above.

${ }^{15}$ Although see the attempts at epidemiological analysis by DeLacy and Seligman, both op. cit., note 2 above.

${ }^{16}$ See, for example, Charles White, An appendix to the second edition of Mr. White's treatise on the management of pregnant and lying-in women, London, printed for E and C Dilly, 1777, pp. 15-16.

${ }^{17}$ Jean Donnison, Midwives and medical men, 2nd ed., London, Historical Publications, 1988; Adrian Wilson, The making of man-midwifery, London, UCL
}

Press, 1995; Loudon, op. cit., note 1 above; idem, Medical care and the general practitioner, 1750-1850, Oxford, Clarendon Press, 1986; idem, 'Medical practitioners 1750-1850 and the period of medical reform in Britain', in A Wear (ed.), Medicine in society, Cambridge University Press, 1992.

${ }^{18}$ Donnison, op. cit., note 17 above, p. 53

${ }^{19}$ Adrian Wilson, 'William Hunter and the varieties of man-midwifery', in Bynum and Porter (eds), op. cit., note 4 above, pp. 343-69.

${ }^{20}$ W F Bynum, 'Physicians, Hospitals and career structures in eighteenth-century London', in Bynum and Porter (eds), op. cit., note 4 above, pp. 105-28; Donnison, op. cit., note 17 above, pp. 53-71. 


\section{The Attempt to Understand Puerperal Fever}

hospitals-were often physician-accoucheurs. Individuals who wrote on puerperal fever were, therefore, likely to combine an interest in midwifery with one of the most important areas of a physician's practice - the treatment of fevers. The particular group of writers under study here contains individuals who possessed both surgical and medical qualifications and experience. Many had both experience as a surgeon and an MD degree.

This paper is based on an examination of literature on puerperal fever published in Britain between the years 1760 and 1850 . Greater attention is paid to treatises than to journal articles, because these provide a more detailed insight into the theoretical perspectives guiding the work of physicians. Certain American texts which appear to have had a particularly strong influence on the British writers have also been included. ${ }^{21}$ Numerous French and other European physicians wrote on puerperal fever. Those of their works which were translated into English and published in Britain have been considered as part of the analysis, and the importance of their influence has been recognized. ${ }^{22}$

The period between 1760 and 1850 can be seen as an important phase in the history of concepts of puerperal fever. Very few works dealing with the subject of fevers in puerperal women - and none on "puerperal fever" per se-were published in Britain before 1760. By 1850 a number of attempts had been made to offer extensive syntheses of knowledge, the most interesting of which were Robert Ferguson's theoretical overview of 1839, and Fleetwood Churchill's narrative history and compilation of $1849 .{ }^{23}$

Medical men wrote as both practitioners and theorists; they saw their work as being grounded in practice, yet they also viewed their theoretical academic work as valuable in itself. Modern scholarship has identified a series of shifting emphases within medicine during the late eighteenth and early nineteenth centuries. This has been viewed as a period in which there was a move from rationalism to empiricism, from the authority of the ancients to a reliance on data, and from nosology to morbid anatomy and the localization of patho$\operatorname{logy} .^{24}$ It has been seen also as the era of the "birth of the clinic" - the development of hospital-based medicine through, perhaps firstly, the advent of the British voluntary hospitals, and later the "revolution" in the Paris hospitals. ${ }^{25}$

Physicians who wrote on puerperal fever identified themselves with what they saw as the ideas of "enlightened" science. They were drawing upon a complex of theories. Reason, based on experience, was claimed by most of the medical writers as the basis of their work. Yet a close reading of the eighteenth- and early-nineteenth-century

\footnotetext{
${ }^{21}$ For example, Charles Meigs, Females and their diseases, Philadelphia, Lea and Blanchard, 1848; Peter de Sales La Terrière, $A$ dissertation on the puerperal fever, Boston, printed by Samuel Hall, 1789; and Mitchell, op. cit., note 5 above.

${ }^{22}$ For example, Jean Astruc, A treatise on the diseases of women, transl. J Nourse, London, printed for J Nourse, 1762, vol. 3; and Baudelocque, op. cit., note 5 above.

${ }^{23} \mathrm{R}$ Ferguson, Essays on the most important diseases of women, London, J Murray, 1839; Churchill (ed.), op. cit., note 9 above.

${ }^{24}$ Christopher Lawrence, 'Ornate physicians and learned artisans: Edinburgh medical men, 1729-1776', in Bynum and Porter (eds), op. cit., note 4 above, pp. 153-76; Andrew Cunningham, 'Medicine to calm
}

the mind: Boerhaave's medical system, and why it was adopted in Edinburgh', in A Cunningham and R French (eds), The medical enlightenment of the eighteenth century, Cambridge University Press, 1990, pp. $40-66$.

${ }^{25}$ Michel Foucault, The birth of the clinic, transl. A Sheridan, London, Routledge, 1973; N D Jewson, 'The disappearance of the sick-man from medical cosmology, 1770-1870', Sociology, 1976, 10: 225-44; E Ackerknecht, Medicine at the Paris hospital, 1794-1848, Baltimore, Johns Hopkins Press, 1967; Bynum and Porter (eds), op. cit., note 4 above; Cunningham and French (eds), op. cit., note 24 above; W F Bynum, Science and the practice of medicine in the nineteenth century, Cambridge University Press, 1994. 


\section{Christine Hallett}

texts reveals that physicians failed at every turn to extricate themselves from a priori assumptions. $^{26}$

The central controversy in the study of puerperal fever during the later eighteenth century remained firmly grounded in the central nosological issue of whether puerperal fever was fundamentally inflammatory or fundamentally putrid. If inflammatory, the fever was a pathological condition of the blood and circulation, which might have originated in the trauma of labour or in other sources of damage to the uterus or other internal organs. It was a disorder of the blood's composition, or of the rate and force with which the blood made its way through the vessels. Thus, it was believed that the most effective treatment would involve copious bleeding of the patient in the earliest stages of the disease. ${ }^{27}$

If putrid, the fever was caused by acrid or morbific matter in the system, which might have been absorbed from outside, perhaps by contagion or as a result of putrid effluvium, or might simply be the result of the suppression of fluids or of obstructed perspiration. ${ }^{28}$ It could be part of a process of decay or mortification, or a manifestation of the body's attempt to throw off dangerous or poisonous matter. ${ }^{29}$

\section{Inflammation: A Mechanistic Explanation}

\section{Theories of Inflammation}

Inflammatory theory was central to the work of eighteenth-century physicians. As an explanatory theory which could both elucidate the nature of fever and offer a means of cure, it appeared to be the most valuable perspective on the subject and retained its power for centuries. The writers of the puerperal fever treatises were particularly strongly influenced by it and it finds its way, to a greater or lesser extent, into all of the works considered here.

The nature of inflammation is assumed, or taken for granted in most of the treatises, though one or two authors attempt to clarify the nature of the process. Inflammation appears to have been explained in terms of the composition - or, more correctly, the consistencyof the blood and its action upon the arteries. If there was, for any reason, a plethora or pooling of blood in any part of the system, a degree of stagnation would result, and the blood would pool. The process appears to have been one in which there was an increased viscidity or thickening of the blood. ${ }^{30}$ This would lead to an increased action in the walls of the arteries in an attempt to re-establish proper circulation. The result would be undue pressure on one

\footnotetext{
${ }^{26}$ See, for example, the numerous references to earlier-including ancient-writers in Hulme, op. cit., note 5 above; see also Mitchell, op. cit., note 5 above, pp. $9-10$.

${ }^{27}$ See, for example, Sir Richard Manningham, The symptoms, nature, causes and cure of the febricula, London, for J Robinson, 1746. On the cause of puerperal fever in the "sudden removal of pressure from the blood vessels at the time of delivery", see Clarke, Practical essays, op. cit., note 5 above; p. 55. On fever as a stagnation of the blood brought about by the cold fit, see J Leake, Practical observations on the child-bed fever, London, for J Walter, 1772, p. 85. See also J Leake, Medical instructions towards the
}

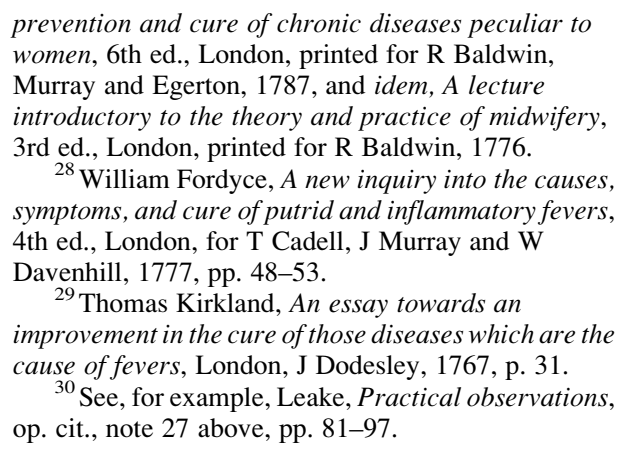

${ }^{30}$ See, for example, Leake, Practical observations, op. cit., note 27 above, pp. 81-97. 


\section{The Attempt to Understand Puerperal Fever}

part of the system, which, if not rapidly resolved, would be transmitted throughout the circulation causing generalized pressure, accompanied by heat. If unresolved, this pressure could lead to a breakdown of the whole system. The original process of pooling was accompanied by — or was perhaps the result of — a generalized increase in the "excitability" of the system. Although writers were not clear what exactly the quality or nature of this "excitability" was, they saw it as being accompanied by a very rapid pulse. ${ }^{31}$ The most valuable means available to the physician of relieving inflammation was bloodletting, which would reduce the hydrostatic pressure in the arteries, a measure recommended, along with the use of purgatives, in almost all of the treatises on the subject. ${ }^{32}$ In fact, bloodletting became an important area of conflict for the writers on puerperal fever. Those who saw the disease as inflammatory in nature advocated frequent and copious bloodletting, particularly in the early stages of the illness, whilst those who saw the disease as putrid argued against bloodletting on the grounds that this would lead to a dangerous degree of debility.

The mechanical perspective on disease, and on fevers in particular, featured prominently in the medical system of the famous Leyden-based professor, Herman Boerhaave. It was a perspective which likened the body to a machine, part of which was a circulatory system that behaved like a set of fluid hydraulic devices, and disease as a disorder in the functioning of this system. ${ }^{33}$ This perspective was one which seems to have corresponded closely with inflammation. In his commentaries on Boerhaave's Aphorisms, the German physician and academic, Baron G F van Swieten, discussed in some detail Boerhaave's views on the nature of inflammation. Van Swieten's commentaries were probably an important text for medical education in the mid- to late eighteenth century. An English translation of 1776 was dedicated to William Cullen. ${ }^{34}$

Boerhaave had observed that inflammation was sometimes called a "phlegmon" or "fire". He had pointed out that "it consists in a greater pressure and attrition of the red arterial blood, stagnating in the smallest vessels, and urged by the motion of the rest of the blood". ${ }^{35}$ In his commentary on this passage, van Swieten argued that, if an inflammation affected one or more of the internal viscera, fever almost invariably ensued. Boerhaave had contended that inflammation could take place anywhere within the blood or lymphatic systems when the mouths of vessels were wide enough to permit the entry of the blood's "red globules", "or the gross particles of some other fluid", but whose lumens then narrowed so that the fluid concerned could not pass through. The causes of this blockage and stagnation of fluids were numerous: pressure, contortion, or erosion, acrid substances either taken as food, or applied externally, severe cold, and contusions, to name but a few.

\footnotetext{
${ }^{31}$ See, for example, Denman, 2nd ed., 1773, op. cit., note 5 above, pp. 11-12. Thomas Denman was born in Bakewell in 1733 . He worked as a navy surgeon until 1763, then went to Aberdeen University where he obtained his MD degree in 1764 . He was "physician-accoucheur" to the Middlesex Hospital from 1769 to 1783 . He died in 1815 .

${ }^{32}$ See, for example, John Aitken, Principles of midwifery: or puerperal medicine, 3rd ed., London, J Murray, 1786, pp. 171-82; Denman, 2nd ed., 1773, op. cit., note 5 above, pp. 17-23.
}

\footnotetext{
${ }^{33}$ Herman Boerhaave, Aphorisms: concerning the knowledge and cure of diseases, transl. by J Delacoste, London, William and John Innys, 1724; idem, Academical lectures on the theory of physic, 6 vols, London, W Innys, 1742-46; G A Lindeboom, Herman Boerhaave: the man and his work, London, Methuen, 1968.

${ }^{34}$ Baron G F van Swieten, Commentaries upon Boerhaave's Aphorisms, 18 vols, Edinburgh, printed for C Elliot, 1776.

${ }^{35}$ Ibid., vol. 3, pp. 245, 248.
} 


\section{Christine Hallett}

In addition, anything acrid which entered the blood vessels themselves and caused them to contract could have a similar effect, as could anything which caused the blood itself to "concrete or cohere", such as "too great motion; a consumption of the thinner parts of the blood by sweats, urine, spitting, or a diarrhoea". ${ }^{36}$ Several volumes of van Swieten's text are devoted to fevers, of which he argues that the "proximate" or more immediate cause is the "velocity or quickness of the pulse" and, in tandem with this, "a quicker contraction of the heart". The link between viscidity of blood, blockage of capillaries and rapidity of pulse is implicit, but clear. ${ }^{37}$ It is easy to see why so many of the features of pregnancy and delivery-most obviously, the pressure of the foetus on the abdominal and pelvic viscera and the damage to tissues that could be caused by delivery-might be seen by eighteenthcentury physicians, versed in the doctrines of Boerhaave, as the causes of inflammation.

The mechanical theory drew heavily on William Harvey's work in establishing the nature of the circulatory system. ${ }^{38}$ In his Academical lectures on the theory of physic, Boerhaave divided the most recent phases in the history of medicine into "Galen to Harvey" and "After Harvey". ${ }^{39}$ By the eighteenth century, mechanism was already an important philosophical tradition, which had, in part, developed in opposition to the animism of the Renaissance period. Eighteenth-century physicians were familiar with the natural philosophy of René Descartes who had suggested that the individual could be viewed as a combination of two components - a mechanical body and a spiritual soul. The mechanical perspective survived throughout the eighteenth century, and found its most extreme exposition in L'homme machine of Julien Offray de la Mettrie. ${ }^{40}$

By the mid-eighteenth century, however, mechanical philosophy was already viewed by many as an overly simplistic explanation for what was clearly the intricate and complex functioning of the human being. Philosophers came to view the assumption that the body was little different from a clockwork machine as profoundly unsatisfying. More complex theories of health and disease began to be developed; for example, a group of Montpellier physicians began to write in terms of vitalist philosophy. ${ }^{41}$ Others likened their perspective to Newtonian theory. Marina Benjamin has argued that this group explained human physiology in terms of "the operation of short-range forces which were seen to be analogous to gravity". 42

\footnotetext{
${ }^{36}$ Ibid. The material on inflammations is contained mainly in vol. 3. See Aphorism 370, p. 245; Aphorism 371, p. 248; Aphorism 372, p. 252; Aphorism 375, p. 261; Aphorism 376, p. 268; Aphorism 377, p. 270; and van Swieten's commentaries on these.

${ }^{37}$ Ibid., vols 4, 5, and 6, see especially, vol. 5, Aphorisms 572 and 573, p. 28.

${ }^{38} \mathrm{See}$, for example, reference being made to the basis in Harvey's findings of inflammatory theory, as late as the 1820s: William Stoker, $A$ dissertation on the institutes of medicine, Dublin, R Milligen, $\mathrm{J}$ Cumming, and Hodges and M'Arthur, 1826, p. 1xvii.

${ }^{39}$ Boerhaave, Academical lectures, op. cit., note 33 above; see also John Hunt, Observations on the circulation of the blood, London, printed for J Johnson, and C Elliot, Edinburgh, 1787.

${ }^{40}$ Dorinda Outram, The Enlightenment, Cambridge University Press, 1995, p. 34.
}

\footnotetext{
${ }^{41}$ Roselyne Rey, 'Vitalism, disease and society', in Roy Porter (ed.), Medicine in the Enlightenment, Amsterdam, Rodopi, 1995; E Haigh, Xavier Bichat and the medical theory of the eighteenth century, Med. Hist. Supplement, No. 4, London, Wellcome Institute for the History of Medicine, 1984. On the medical perspective, see Thomas Morgan, The mechanical practice of physick, London, T Woodward, 1735 .

${ }^{42}$ Marina Benjamin, 'Medicine, mortality and the politics of Berkeley's tar-water', in Cunningham and French, op. cit., note 24 above, pp. 165-93, on p. 171. Julian Martin refers to the British Newtonian physicians Pitcairne, Cheyne, Keill, Arbuthnot, Hales, Jurn and Wainewright, in 'Sauvages's nosology: medical enlightenment in Montpellier', in Cunningham and French (eds), op. cit., note 24 above, pp. 111-37, on p. 131 .
} 


\section{The Attempt to Understand Puerperal Fever}

Many of the treatises considered here appear to have been influenced by the teachings and writings of the Edinburgh professor, William Cullen. In his First lines of the practice of physic, Cullen had argued that fevers should be explained in terms of "solidism", focusing on the effects of certain "noxious powers" on the nervous system. He did, however, see spasm of various elements of the circulatory system as part of the process, arguing that "in inflammatory diseases there is a diathesis phlogistica prevailing in the body, and this diathesis we suppose to consist in an increased tone of the whole of the arterial system". 43 In other fevers, however, there was no "diathesis phlogistica", and the symptoms were associated more with debility than spasm. Where the former tended to be referred to as "inflammatory" fevers, the latter were "nervous". 44

Cullen distinguished between a number of types of "pyrexiae, or febrile diseases", separating the genus of "fevers" from that of "inflammations". ${ }^{45}$ Hence, when later writers on diseases such as puerperal fever drew upon Cullen's ideas, their theories could appear to be a curious amalgam of theories about both types of condition. Cullen observed that inflammation was characterized by "redness, heat, pain and tumour", which, if severe, could give rise to a "pyrexia" of the whole system. If internal organs were affected, there could be fixed pain and "interruption of function". The state of the blood was a good indicator of inflammation in the system. Blood normally consisted of a fluid with a thin element known as "serum", a thicker component called the "crassamentum", and a whitish, more solid component, known as the "gluten" or "coagulable lymph". When drawn and allowed to cool, inflamed blood would indicate a portion of the gluten separated from the rest of the mass, and lying on the surface of the crassamentum, in a state often referred to as an "inflammatory crust". ${ }^{46}$

Once one part of the system had become affected by spasm, this was automatically transmitted to the rest, in the process already referred to as a "diathesis phlogistica". People with "rigid fibres" were prone to this condition, which could be brought on by anything with tonic or astringent properties, particularly cold. In inflammation, therefore, a general diathesis frequently arises from inflammation "begun in a particular part", and can be removed by the "relaxing power of bloodletting". 47

Eighteenth- and nineteenth-century writers on puerperal fever were also deeply influenced by Cullen's ideas on the "terminations" of inflammations, which were seen to take on any of three forms: "resolution", "suppuration" or "gangrene". ${ }^{48}$ In resolution, the spasm of the arteries was overcome by an increased blood flow, and the congestion was removed, restoring the affected part to "its ordinary and healthy state". Resolution could be assisted by the movement of fluid into some neighbouring part of the body or into

\footnotetext{
${ }^{43}$ William Cullen, First lines of the practice of physic, 4 vols, London, printed for J Murray; Edinburgh, printed for William Creech, 1777-1784, vol. 1, pp. 54-5. See also, C Clayson, 'William Cullen in eighteenth century medicine', in A Doig, J P S Ferguson, I A Milne, and R Passmore (eds), William Cullen and the 18th century medical world, Edinburgh University Press, 1993, pp. 87-97;

G B Risse, 'Cullen as clinician: organisation and strategies of an eighteenth century medical practice', in the same volume, pp. 133-51.

${ }^{44}$ Cullen, op. cit., see note 43 above, pp. 55-60.
}

\footnotetext{
${ }^{45}$ Ibid., Book 1 of vol.1 is on fevers, Book 2 is on inflammations or phlegmasiae.

${ }^{46}$ On the nature of the blood, see William Cullen, Institutions of medicine. Part I: Physiology, 3rd ed., Edinburgh, Charles Elliot; London, T Cadell, 1785. pp. 192-4. On the changes which take place in inflammation, see also Cullen, First lines, op. cit., note 43 above, pp. 181-5; Fordyce, op. cit., note 6 above, pp. 23-4.

${ }^{47}$ Cullen, op. cit., note 43 above, pp. 189-93.
${ }^{48}$ Ibid., pp. 190-204.
} 


\section{Christine Hallett}

"the adjoining cellular texture", or by the removal of blood in some other part of the system which relieved the "phlogistic diathesis". 49

Suppuration occurred when the mechanism described above took place in a dangerous or extreme way, in particular, "if the increased impetus of the blood in an inflamed part dilates the exhalant vessels to such a degree, that they pour out an entire serum". This serum could stagnate. The gluten in it changed into a "white opaque, moderately viscid, mild liquor, which we name pus". If a collection of pus was formed in an inflamed part this was called an "abscess". The presence of the pus may erode the solid parts of the organ affectedsometimes to the extent that an open ulcer was produced. ${ }^{50}$

The termination of an inflammation in "gangrene" indicated that the matter effused had been "tainted with a putrid ferment", thus producing "more or less complete putrefaction". If this also affected vessels and muscles, it was referred to as a "sphacelus". Gangrene and sphacelus might arise because of the extent of stagnation of the serum effused, or they might be due to the fact that the fluids of the body were already predisposed to extreme putrefaction. $^{51}$

The fact that inflammatory theory centred primarily around an understanding of the state of the blood and the circulatory system meant that physicians emphasized the need for an intimate understanding of the pulse. Good practice depended on the meanings and interpretations that could be placed on its strength and rate. ${ }^{52}$ The corollary of this was, of course, that it was helpful for the physician to know the patient well; he needed to be aware of what constituted "normal" for the individual.

\section{Inflammation Theory in the Puerperal Fever Treatises}

One of the earliest applications of inflammation theory to puerperal fever was that of Sir Richard Manningham, whose work viewed fever in terms of a "viscidity or lentor in the blood". 53 In this treatise, Manningham used the term "lentor" in its technical sense to refer to a thickening of the blood's consistency. Perhaps the most valuable discussion of the

\footnotetext{
${ }^{49}$ Ibid., pp. 191-6, 204-5.

${ }^{50}$ Ibid., pp. 192-200.

${ }^{51}$ Ibid., pp. 197-202. Cullen also mentions other rarer terminations: "schirus [sic], or indolent hardness", and, in the case of inflammation of internal organs, the production of a "viscid concretion" and a "thin serous fluid", pp. 201-2.

${ }^{52}$ Fordyce, op. cit., note 6 above, pp. 43-6. On the "cold" and "hot fits" see also p. 48.

${ }^{53}$ Sir Richard Manningham, The symptoms, nature, causes and cure of the febricula, 2nd ed., London, for J Robinson, 1750, p. 29. Sir Richard Manningham was physician to the lying-in Infirmary of London during the mid-eighteenth-century. A number of other eighteenth-century writers were expressing similar ideas. Jean Astruc's influential A treatise on the diseases of women, of 1762 (op. cit., note 22 above), presented puerperal fever as an essentially inflammatory condition caused by suppression of the lochia following delivery. He added that the disease
}

can become putrid through a simple process of suppuration. In his treatise of 1793, John Clarke explained how the inflammatory characteristics of puerperal fever could produce the typical symptoms of the disease: pain in the lower abdomen, diminution of the lochia, suppression of the milk, and more generalized systemic symptoms such as heat; rapidity, strength and fullness of the pulse; white, dry tongue; thirst; headache; vomiting and diarrhoea. Clarke, Practical essays, op. cit., note 5 above, pp. 62-80. See also John Aitken, Principles of midwifery, 3rd ed., London, J Murray, 1786, pp. 171-8; Denman, 2nd ed., 1773, op. cit., note 5 above, p. 3. For examples of discussions of inflammation in inaugural dissertations, see Henricus Slaughter, Dissertatio medica inauguralis, de febre puerperali, Edinburgh, Balfour and Smellie, 1780; Thomas Evory, Dissertatio medica inauguralis, de febre puerperarum, Edinburgh, Balfour and Smellie, 1782. 


\section{The Attempt to Understand Puerperal Fever}

nature of inflammation can, however, be found in John Leake's 1772 treatise, Practical observations on the childbed fever. He focused on what he saw as the origin of puerperal fever in inflammation related to stagnation of the blood, brought on by the "cold fit" of the fever. He observed that puerperal fever began as an inflammation of the abdominal viscera and also, more particularly, of the omentum, which was caused by plethora of the blood. The inflammation resulted in suppuration which could increase in putrescency and then become infectious. ${ }^{54}$ This view was shared, in large part, by Nathaniel Hulme. ${ }^{55}$

Leake observed that the inflammatory process of puerperal fever began as a mechanistic one. Blood pooled in the abdominal viscera, especially in the omentum, as a reaction to release of pressure within the abdomen after birth. As pressure was released from the aorta, the main arteries and the small abdominal vessels, blood would "rush into those vessels with a force superior to their resistance, and by putting them violently on the stretch, may occasion pain, inflammation and fever". 56 This occurred most readily in the omentum and intestines where the blood vessels were "numerous and most yielding". ${ }^{7}$ Along with the local inflammation of the abdominal viscera, the diversion of a large volume of blood into the lower abdomen caused deficiency elsewhere, particularly in the heart and brain, which was rapidly followed by an over-compensation and the pooling of blood in these organs once more, accompanied by "anxiety and oppression at the breast and praecordia". 58 The "cold fit" which followed was caused by a draining of blood from the extremities, and the vomiting and diarrhoea which may accompany this were the result of a pooling of blood in the "vena portae ventralis", leading to the excessive secretion of bile. ${ }^{59}$ Leake's description of the effects of puerperal fever offers a vivid account of mechanistic and hydraulic movements of blood within the circulatory system, redolent of an almost tidal sense of blood washing rapidly into and out of the small vessels, creating alternately heat and cold, pain and relaxation. In this way the physician makes sense of the apparently confusing symptoms of fever with its hot and cold fits and its localized pains and generalized discomfort. ${ }^{60}$

${ }^{54}$ Leake, Practical observations, note 27 above, pp. 81-97. John Leake was born in Ainstable in Cumberland. He obtained his MD from Rheims in 1763. He was made a licentiate of the Royal College of Physicians of London in 1766, and became First Physician of the Westminster Lying-in Hospital. He died in 1792. See also: Evory, op. cit., note 53 above, pp. 19-34.

${ }^{55}$ Hulme, op. cit., note 5 above, pp. 147-75. Nathaniel Hulme was born in Yorkshire in 1732. He obtained his MD from Edinburgh University in 1765. During the 1770s he was physician to the Charterhouse and to the London Lying-in Hospital.

${ }^{56}$ Leake, Observations on the child-bed fever (1772), in Churchill (ed.), op. cit., note 9 above, p. 145. John Clarke discusses how "from the sudden removal of pressure from the blood vessels at the time of delivery, a greater proportion of fluids than circulate there in a natural state may rush upon some particular part": Clarke, Practical essays, op. cit., note 5 above. p. 55; see also Campbell, op. cit., note 5 above pp. 196-201.

\footnotetext{
${ }^{57}$ Leake, op. cit., note 56 above, p. 145. For
} Cullen's discussion of inflammation of the intestines, which may have influenced Leake, see Cullen, op. cit., note 43 above, pp. $315-18$.

${ }^{58}$ Leake, op. cit., note 56 above, p. 146. Moore, in his treatise of 1836 , summarized earlier perspectives on inflammation, observing that some had attributed it to an "increased action" of the blood vessels, whilst others had seen it as the consequence of the "act of dilatation" of vessels, which are acting "with less force than the trunks from which they are derived". He pointed out that these hypotheses are complementary rather than contradictory. Moore, op. cit., note 10 above, pp. 94-5.

${ }^{59}$ Leake, op. cit., note 56 above, p. 146. On the stagnation of the blood brought on by the cold fit, see also original version op. cit. note 27 above, pp. 83-5. See also Leake, A lecture, op. cit. note 27 above, p. 16, and Leake, Medical instructions, op. cit., note 27 above, p. 159.

${ }^{60}$ On these issues and on the dangers of "tight binding" the abdomen, see Denman, op. cit., note 5 above, 1st ed., 1768, p. 19; 2nd ed. 1773, p. 7. On 


\section{Christine Hallett}

Physicians also drew upon solidist explanations of the tension of fibres-particularly nerves-which accompanied the inflammatory process, producing suppuration of previously inflamed and irritated tissue, leading to putrefaction. Leake believed that the constitution was rendered "tender" and "irritable" as a result of pregnancy itself, and that this state added to the excitability of the constitution. ${ }^{61}$

Leake, in common with most of his contemporaries, saw putrefaction as the natural consequence of untreated inflammation. In the case of puerperal fever, the process that took place was a "putrid dissolution of the omentum" followed by further corruption of the purulent fluid which resulted. In this way, a fever which was initially "truly inflammatory" became putrid by an absorption of fluid which "like an old leaven, will taint the blood, and by exciting a putrid ferment in the whole mass, will change its qualities into those of its own morbid nature". 62

Alexander Gordon was perhaps the most insistent of those who claimed that the origin of puerperal fever lay in an inflammatory process, ${ }^{63}$ and he emphasized the need to bleed and purge the patient as copiously and as early in the disease as possible:

Whenever a patient complained of a fixed pain in the abdomen, attended with fever, I bled and purged her without regard to the cause. And I found this treatment equally successful in every case, when those symptoms were present, whatever was the cause of the disease. ${ }^{64}$

Gordon's treatise is interesting for two reasons: firstly, he emphasized inflammation. Secondly, he stressed that puerperal fever could be transmitted from one woman to another by the birth attendant. In reconciling these two theories, which are not at first sight obviously compatible, he argued that (as, for example, in inoculation for smallpox) the application of putrid matter to a wound produced, in the first instance, an inflammatory condition. He also cited the fact that,

if in the dissection of a putrid body, a surgeon scratch his finger, the part festers, that is, inflames and suppurates; and if a fever should be the consequence, it is inflammatory in the beginning and only ultimately putrid. ${ }^{65}$

Most of the late-eighteenth and early-nineteenth-century writers on puerperal fever viewed inflammation as a consequence of pregnancy and childbirth, which were, in themselves, processes likely to increase the level of excitability in the system. For example, Thomas Denman observed in 1768 that if one examined the blood of pregnant women, it was found to have an inflammatory "appearance", even in those who did not actually evince symptoms of fever. ${ }^{66}$ Gordon, whose treatise of 1795 was written with the primary purpose

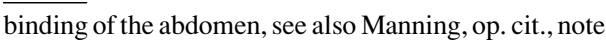
5 above, p. 397; and Campbell, op. cit., note 5 above, pp. 20, 202-3.

${ }^{61}$ Leake, op. cit., note 56 above, pp. 147-9.

${ }^{62}$ Ibid., p. 150; La Terrière, op. cit. note 21 above, p. 8; pp. 15-17; Mitchell, op. cit. note 5 above, p. 5; p. 19. Mitchell's work-like La Terrière's-is noted here in acknowledgement of the fact that British and North American treatise writers had a profound influence on each other during this period. On North American medicine, see Helen Brock, 'North America, a western outpost of European medicine', in Cunningham, and French (eds), op. cit., note 24 above, pp. 194-216.

${ }^{63}$ Alexander Gordon was Physician to the Aberdeen Infirmary in the mid-1790s and had an important private practice as a man-midwife in Aberdeen.

${ }^{64}$ Gordon, op. cit. note 5 above, p. 119. For a clear exposition of Gordon's ideas on the inflammatory nature of puerperal fever, see pp. 52-5.

${ }^{65}$ Ibid., pp. 115-16.

${ }^{66}$ Denman, 2nd ed., 1773, op. cit., note 5 above, p. 3. 


\section{The Attempt to Understand Puerperal Fever}

of demonstrating the inflammatory nature of puerperal fever, emphasized this inflammatory condition of the blood. It had, indeed, a "thick inflammatory crust". ${ }^{67}$

This interest in the composition of the blood found its way into the majority of the treatises. William Campbell, writing in the early 1820s, described its appearance as exhibiting a "thick, firm, buffy coat" or "crust", a "crassamentum" and a high coloured serum. ${ }^{68}$ Campbell gave a clear exposition of the theory that pregnancy and childbirth were likely to predispose a woman to inflammation of the abdominal contents. He observed that "from the moment gestation has taken place, there is a determination of blood towards the uterine system" leading to congestion of the arteries, veins, lymphatics and nerves of this organ. ${ }^{69}$

There was much debate about the value of suggestions that inflammation was a "natural" feature of childbirth, some physicians arguing that it offered the obvious explanation for conditions such as puerperal fever, others maintaining that it did not explain why all women did not suffer from such fevers. ${ }^{70}$ In attempting to understand how puerperal fever could arise in some, but not all, women, physicians took the view that, whilst all parturient women had a natural tendency towards fever, only those in whom there were predisposing factors were at serious risk. ${ }^{71}$

In his publication of 1839 , Robert Ferguson argued that any sort of damage or injury to the placenta during childbirth could have dangerous consequences, by setting up a reaction that led to puerperal fever. ${ }^{72}$ His description of the nature of this reaction is not clear, but its basis appears to lie in the production, by damaged, torn and subsequently inflamed arteries, of dangerous fluids, which will then circulate through the system. He believed that any sort of injury could lead to this effect; for example, manual separation of the placenta, "longcontinued afterpains" and "instrumental operations, and all such cases as directly bruise or disturb the wound". All of these effects "create diseased secretions from the traumatic

\footnotetext{
${ }^{67}$ Gordon, op. cit. note 5 above, p. 9. See also, Clarke, Practical essays, op. cit., note 5 above, p. 12: "the blood drawn from women in pregnancy is generally covered with a buff, the red globules having fallen to the bottom of the cake".

${ }^{68}$ Campbell, op. cit. note 5 above, p. 46.

${ }^{69}$ Ibid., pp. 195-6. On the inflammatory nature of puerperal fever, see also pp. 197-201. Campbell cites in support of his view of puerperal fever as an inflammatory complaint, William Hunter, John Hunter, Denman, Leake and Gordon.

${ }^{70}$ See, for example, Ferguson, op. cit. note 23 above, pp. 98-100. Moore, op. cit., note 10 above, p. 106.

${ }^{71}$ In his treatise of 1768 , Thomas Denman stated that these predisposing factors could include difficult labours, and constipation, see note 5 above, pp. 17-19. Henry Manning suggested that they might include "accidents after delivery", "sudden frights" and "too hasty a separation of the placenta", op. cit., note 5 above, p. 397. In 1751, Burton observed that inflammation of the uterus could be caused either by damage inflicted by the midwife, or by the suppression of lochia, thus demonstrating the links between the
}

mechanistic way of thinking and the notion of suppressed fluids; John Burton, An essay towards a complete new system of midwifry [sic], London, $\mathrm{J}$ Hodges, 1751: on suppression of the lochia, see pp. 334-40; on inflammation of the uterus, pp. 335-7. Burton's ideas are also cited by Hulme, op. cit., note 5 above, pp. 88-146. The French physician, Astruc, observed in 1762 that the excitability which caused inflammation was occasioned by allowing cold air into the uterus (which would cause it to contract spasmodically), by a pre-existing diarrhoea, by damage to the uterus during childbirth, or by "passions of the mind", thus raising echoes of the "non-naturals" discussed by earlier authors. Astruc, op. cit., note 22 above, pp. 227-30.

${ }^{72}$ Robert Ferguson was born in India in 1799. He obtained his MD from Edinburgh in 1823. He became a licentiate of the Royal College of Physicians in 1824; physician to the Westminster Lying-in Hospital; Professor of Midwifery at Kings College in 1831; Fellow of the Royal College of Physicians in 1837, "Physician-Accoucheur" to the Queen in 1840 and "Physician-Extraordinary" to the Queen in 1857. 


\section{Christine Hallett}

surface, or irritate its large pendulous lacerated vessels, and so give rise to the phenomena of puerperal fever". 73

The advice about regimen which was given to women during the puerperium was designed mainly to prevent overheating, excessive stimulation and "plethora" within the system. Prevention could be achieved by avoiding "heating" foods-particularly meat - and stimulating drinks — such as the spicy caudles which were given by midwives as part of traditional practice during labour and immediately after delivery. Clarke's perspective on this practice was extremely forthright, and mirrored the views of his colleagues, who were unanimous on the dangers of caudles:

Nothing can be more false in principle, nor more destructive in its tendency ... If they do any thing, they will most certainly increase the action of the heart and arterial system beyond that degree which the mere exertions of labour will produce. $^{74}$

Clarke's discussion of the dangers of stimulating drinks is interesting for two reasons: firstly, the statement that this measure is both "false in principle" and "destructive in its tendency" offers an interesting insight into Clarke's perception of himself as both a coherent theoretician and an empiricist. Secondly, this argument is used by Clarke, as also by other physicians, as a means to attack traditional practice. Clarke uses terms such as "activity", "stimulate" and "increase the action". 75 These are characteristic of explanations based in inflammatory theory, but are never, themselves, clearly explained. They are also employed in discussions of the dangers of excessive interference in labour, as, for example, in the unnecessary use of instruments or the attempt to dilate the cervix by artificial means. ${ }^{76}$

One important variant on inflammatory theory-and one that was given much credence by a number of authors throughout the late eighteenth and first half of the nineteenth centuries-was the view that this inflammation arose, not in the uterus itself, but in other abdominal organs-particularly the omentum and/or the intestines. This theory, which was most firmly espoused by Leake and Hulme in their treatises of 1772, fitted well with the idea that inflammation resulted directly from pressure on the abdominal viscera which, when suddenly released, gave rise to a lentor of the blood. ${ }^{77}$ Hulme even suggested that the spasmodic contraction of uterine vessels might be a secondary

\footnotetext{
${ }^{73}$ Ferguson, op. cit., note 23 above, p. 106. On the dangers of retained placenta, see Robert Lee, 'Clinical reports of difficult cases in midwifery',

Lond.med. Gaz., 1838-39, 2: 554-62; 665-70; 713-17; 872-7; 908-10; idem, Pathological and practical researches on the uterine inflammation in puerperal women, London, printed by G Woodfall, 1831, pp. 58-9. See also Campbell, op. cit., note 5 above, on the dangers of forcible removal of the placenta, pp. 203-5; on "severe labours", pp. 205-10; on the effects of cold, pp. 211-12. On the link between puerperal fever and damage caused during labour, see Clarke, Practical essays, op. cit., note 5 above, p. 17.

${ }^{74}$ Clarke, Practical essays, op. cit., note 5 above, pp. 19-20. For a later discussion of the same issue, reaching very similar conclusions, see Armstrong, op. cit., note 5 above, pp. 42-44.
}

\footnotetext{
${ }^{75}$ Ibid., p. 20. On the dangers of "the too early use of cordials and stimuli" see also, Campbell, op. cit., note 5 above, p. 212.

${ }^{76}$ Clarke, Practical essays, op. cit., note 5 above, pp. 20-1. On the likelihood that midwives will cause damage to the "os uteri", see Astruc, op. cit., note 22 above, pp. 227-30. On damage caused during delivery, see Baudelocque, op. cit., see note 5 above, pp. 54-64; on retention of placenta, pp. 98-110.

${ }^{77}$ Hulme, A treatise on the puerperal fever (1772), in Churchill (ed.), op. cit., note 9 above, esp. pp. 69, 103; Leake, op. cit., note 56 above, p. 145. This view was also held by Joseph Clarke, physician at the Dublin lying-in hospital in the late eighteenth century, see his 'Observations on the puerperal fever', Edinburgh Medical Commentaries, 1790, 15: 299, reprinted in Churchill (ed.), pp. 351-62, esp. pp. 355-6.
} 


\section{The Attempt to Understand Puerperal Fever}

consequence of the pain attendant on the primary site of inflammation-the omentum. ${ }^{78} \mathrm{He}$ asserted that puerperal fever was directly caused by interruption of blood flow consequent upon pressure from the gravid uterus. "The vessels become completely filled with blood, and are ripe for inflammation". ${ }^{79}$ This theory was refuted by Thomas Kirkland, who argued that, if this were the cause of puerperal fever, the disease would be much more prevalent and much more uniformly distributed across the population than in fact it was. ${ }^{80}$ Physicians used evidence from morbid anatomy to support their arguments. Both Hulme and Leake used evidence from dissections to confirm that the inflammation of puerperal fever originated in the omentum. Other physicians produced different findings, and the variation in morbid appearances could be confusing. Clarke observed that,

In most instances there has been some degree of inflammation in the cavity of the abdomen;- - but it has not been confined invariably to any particular part-sometimes the intestines, sometimes the stomach, sometimes the liver, sometimes the investing membrane lining the muscles have been inflamed. ${ }^{81}$

Clarke was non-committal about the origins of this fever. He expressed uncertainty about whether inflammation was the basis of the disease, or simply its sequela. ${ }^{82}$ In his later treatise of 1793, he presented a more sophisticated, complex perspective on puerperal fever, which was clearly the result of years of further empirical and theoretical work. He now argued that puerperal fever could take any one of a number of different forms, which he organized into a complex classification, and that some of these were caused by inflammation-usually brought on by a plethora. ${ }^{83}$

Having understood puerperal fever as an inflammatory condition caused by an excitability originating in the circulatory system, some authors went on to discuss the possible sequelae of this condition. Leake, in his publication of 1772, observed that this process could lead either to "critical evacuation", usually in the form of diarrhoea (an essentially humoralist idea), to the formation of an abscess, or to gangrene. ${ }^{84}$ Gordon offered an interesting interpretation of the various sequelae of puerperal fever. He argued, in his 1795 account of an epidemic in Aberdeen, that of those women who survived the epidemic, "the greater part owed their recovery to such evacuations, as cure inflammatory diseases". In some cases, the evacuations were promoted by the physician through the techniques of bleeding and purging, in others, they were natural and spontaneous. In some cases there was a "translation of the inflammation to the extremities", producing erysipelas or an abscess, and in others he had observed "an astonishing effort of nature, in discharging the abdominal suppuration by an external outlet". ${ }^{85}$

\footnotetext{
${ }^{78}$ Hulme, op. cit., note 77 above, p. 69.

${ }^{79}$ Ibid., p. 106. For a much later, nineteenth-century perspective on the affection of the intestines in puerperal fever, see John Burns, The principles of midwifery, 3rd ed., London, Longman, Hurst, Rees, Orme and Brown, 1814, p. 427.

${ }^{80}$ Thomas Kirkland, An essay on childbed fevers, etc., in Churchill (ed.), op. cit., note 9 above, pp. 291-2.

${ }^{81}$ Clarke, An essay on the epidemic disease, op. cit., note 5 above, p. 33 .

${ }^{82}$ Ibid., pp. 28, 34-5.
}

\footnotetext{
${ }^{83}$ Clarke, Practical essays, op. cit., see note 5 above, pp. 51-170.

${ }^{84}$ Leake, Practical observations on the child-bed fever, op. cit., note 27 above, pp. 49-50, 80, 84-5, 145 See also Aitken, op. cit., note 32 above, pp. 171-8.

${ }^{85}$ Gordon, op. cit., see note 5 above, p. 53. Gordon gave a number of cases of the latter type of crisis: in the case of Janet Cormack, a release of purulent matter took place through the umbilicus; in the case of Thomas McRoberts' wife, there was an erysipelas of one of the arms accompanied by a severe diarrhoea, and in the case of Isaac Allen's wife
} 


\section{Christine Hallett}

Gordon argued at length that those physicians who took puerperal fever to be putrid in its essential character had been mistaken in taking the sequelae of the condition as its basic sign:

Putrescency is only the effect, or consequence, of previous inflammation neglected, or improperly treated. For, in the course of the disease, considerable extravasation takes place into the cavity of the abdomen; and the matter thus extravasated, by stagnation, must soon acquire an acrid and putrescent quality, and, being absorbed, will occasion putrid symptoms. ${ }^{86}$

Modern historians have taken a great interest in the link between puerperal fever and erysipelas. Working with the knowledge of hindsight and observing that both erysipelas and puerperal fever were "eventually discovered" to be caused by streptococcal infection, they have emphasized this link to, perhaps, a greater extent than the treatise writers themselves. ${ }^{87}$ Some have also erroneously attributed its "discovery" to one of the "heroes" of puerperal fever historiography, Alexander Gordon. ${ }^{88}$ Gordon did mention the coincidence of erysipelatous conditions and puerperal fever, but he was not the first writer to do so. In 1773, Denman had commented on a "peculiarity" in puerperal fever which he believed had never been noticed before-namely "an erysipelatous appearance of a dusky red colour on the knuckles, wrists, elbows, knees, or ankles, about the size of a shilling and sometimes larger" ${ }^{89}$ Fifteen years later, in his account of the epidemic lasting from 1787 to 1788, John Clarke also mentioned the relevance of "erysipelas" to this disease. ${ }^{90}$ Philip Pitt Walsh, whilst arguing that puerperal fever was a manifestation of the category "synochus", also stated that the inflammation involved was of an erysipelatous kind..$^{91}$

\section{The Influence of Morbid Anatomy on Theories of Puerperal Fever}

From about 1790 onwards, theories of inflammation came to be heavily influenced by the development of pathology and morbid anatomy. The writings and teachings of French anatomists such as Pierre Louis had a particularly strong influence on the study of fevers in the first half of the nineteenth century. ${ }^{92}$ This influence is clearly much more marked in the early-nineteenth-century works of individuals such as Gooch and Ferguson than in the eighteenth-century writings of those such as Leake and White.

In his treatise of 1829, Robert Gooch exhorted the student of puerperal fever to "make yourself perfect in the art of examining dead bodies; accustom your hand to open them, and

there was a "discharge of purulent matter from the urethra". Ibid: on Cormack, pp. 41-2; on McRoberts, pp. 44-7; on Allen, pp. 47-9.

${ }^{86}$ Ibid., p. 54.

${ }^{87}$ See, for example, DeLacy, op. cit., see note 2 above, pp. 521-56. Loudon, op. cit., see note 1 above, passim, esp. pp. 11-12.

${ }^{88} \mathrm{~K}$ Kiple, 'Ergotism and erysipelas: Saint Anthony's Fire', in K Kiple, (ed.), Plague, pox and pestilence, London, Weidenfeld and Nicolson, 1997, p. 37.

${ }^{89}$ It is uncertain who was actually the first to make this link, but it was certainly made by Thomas Denman, 2nd ed., 1773, op. cit., see note 5 above, p. 13. Gordon himself refers to puerperal fever as being "of the nature of ... erysipelas [rather than] phlegmon", adding, however, that the usual cures for erysipelas were not effective in this disorder. Gordon, op. cit., note 5 above, p. 55.

${ }_{90}^{90}$ Clarke, An essay on the epidemic disease, op. cit., note 5 above, p. 11 .

${ }^{91}$ Walsh, op. cit., note 5 above, pp. $17-18$.

${ }^{92} \mathrm{~L}$ G Wilson, 'Fevers and science in early nineteenth century medicine', J. Hist. Med., 1978, 33: 386-407, pp. 394-8; D C Smith, 


\section{The Attempt to Understand Puerperal Fever}

your eye to detect with accuracy morbid appearances". ${ }^{93}$ His contemporary, George Moore, observed that "fatal fever, of every kind, is almost invariably connected with inflammatory changes of structure". 94

The evidence from dissections was often used to demonstrate that the process of inflammation had taken place in the abdominal and pelvic cavities of puerperal fever sufferers. There were those, however, who cautioned against excessive reliance on evidence from dissections. Charles White, for example, was very wary of the manner in which some of his contemporaries extrapolated from morbid signs of inflammation in the dissected patient to a claim that the disease was fundamentally inflammatory. His view, he stressed, was that the damage caused by acrid matter produced during putrefaction could create an inflammatory response in one or more organs, adding further that some apparently inflammatory appearances might have been produced by the process of mortification during and after death, and not by the disease process at all. ${ }^{95}$

Nevertheless, in spite of such warnings, the late-eighteenth- and early-nineteenth-century writers on puerperal fever became increasingly heavily influenced by evidence from dissections. Morbid anatomy continued to fuel the endeavours of physicians to identify inflammatory processes in specific organs of the body. This, in turn, fuelled a proliferation of nosological categories and explanations for puerperal fever. Amongst the earliest writers on this subject were Leake and Hulme, both of whom had located the origin of the fever in the omentum and intestines. ${ }^{96}$ Later writers agreed with their views on the inflammatory nature of the disease, but disputed their suggestion that the omentum was its "seat". Gordon, Armstrong and Hey all emphasized the involvement of the whole of the peritoneum. ${ }^{97}$

Several years later, in his publication of 1829 , Gooch asserted unequivocally that puerperal fever was fundamentally an inflammation of the peritoneum, and should, more correctly, be named puerperal peritonitis. ${ }^{98}$ In the same year, a publication by the Dublin-based physician, Samuel Cusack, referred to puerperal fever as "puerperal abdominal inflammation", arguing that there were not sufficient differences between puerperal fever and peritoneal inflammation to make it worthwhile viewing them as distinct diseases. ${ }^{99}$ The idea that puerperal fever was a form of peritonitis was also finding its way into more general textbooks in the 1820s. For example, Samuel Ashwell, in his Practical treatise on parturition of 1828, objected to the term "puerperal fever", as being inappropriate to a disease which was clearly an inflammation of the peritoneum. $^{100}$

'Gerhard's distinction between typhoid and typhus and its reception in America, 1833-1860', Bull. Hist. Med., 1980, 54: 368-85, p. 369.

${ }_{93}$ Gooch, op. cit., note 5 above, Preface, p. xi.

${ }^{94}$ Moore, op. cit., note 10 above, p. 104.

${ }^{95}$ Charles White, A treatise on the management of pregnant and lying-in women (1773), in Churchill (ed.), op. cit., note 9 above, p. 260; White, op. cit., note 16 above, p. 30 .

${ }^{96}$ Leake, op. cit., note 56 above, pp. 118 , 136; Hulme, op. cit., note 77 above, pp. 66, 79-88, 105-7.

\footnotetext{
${ }^{97}$ Gordon, op. cit., note 5 above; Armstrong, op. cit., note 5 above, Preface; Hey, op. cit., note 13 above, Preface.

${ }^{98}$ Gooch, op. cit., note 5 above, p. 62.

${ }^{99}$ Cusack, op. cit., note 6 above, p. 2.

${ }^{100}$ Samuel Ashwell, A practical treatise on parturition, London, T Tegg, 1828, pp. 493-4. The influential French treatise by Baudelocque also presented this disease as "puerperal peritonitis". Baudelocque, op. cit., note 5 above; on "the lesions observed in the peritoneum after death", see pp. 273-90.
} 


\section{Christine Hallett}

\section{The Idea of Putrefaction in the Treatises}

\section{Arguments against Inflammation Theory}

Although most theorists saw puerperal fever as inflammatory, a few adopted the opposing view that inflammation was a consequence and an appearance-rather than a cause - of the condition. Those physicians who were more interested in putrefaction than inflammation tended to play down the role of inflammation in the origin of the disease. Charles White, for example, observed that "it does not appear that this disorder can be ascribed to simple inflammation". ${ }^{101}$ William Butter and Philip Pitt Walsh also argued against the centrality of inflammatory theory. Butter saw all fevers as disorders of the "first passages" (that is, the alimentary canal) ${ }^{102}$ whilst Walsh argued that puerperal fever was essentially a "synochus"- a disease of debility rather than excitability or inflammation. ${ }^{103}$

Generally speaking, those theorists who favoured an explanation of puerperal fever grounded upon ideas about putrefaction were more likely to make use of "solidist" explanations. Furthermore, those physicians whose perspective was more clearly or "purely" solidist—such as Thomas Kirkland — were likely to refute inflammatory explanations of the origin of this disease. Kirkland accepted that spasms of the nerves and muscles during delivery did lead to obstructions of "small vessels", yet emphasized that inflammation followed from rather than caused other events. ${ }^{104}$ Nevertheless, in his treatise of 1774 , Kirkland did state:

I believe it is a certain fact, whatever may be the cause of a puerperal fever, that within a limited time the whole abdomen is more or less inflamed; because the belly always turns green and putrid, in a very short time after death. ${ }^{105}$

Hence, inflammation still makes an important appearance in what Kirkland sees as the natural history of the disease. ${ }^{106}$

${ }^{101}$ White, A treatise, op. cit., note 95 above, p. 213. White did, however, write a new edition of this work in 1777, to which he added an Appendix dealing entirely with the nature of puerperal fever: White, op. cit., note 16 above.

${ }^{102}$ Butter, op. cit., note 5 above, pp. viii, 18.

${ }^{103}$ Walsh, op. cit., note 5 above, p. 16. Philip Pitt Walsh was physician to the General Lying-in Hospital, Consulting Physician to the General Lying-in Dispensary and Physician to the British Lying-in Hospital. 292.

${ }^{104}$ Kirkland, op. cit., see note 80 above, pp. 286,

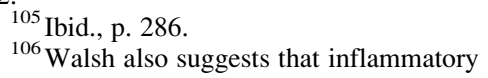
symptoms may accompany "diseases of debility", which are usually viewed as putrid types - or fevers of the classification "typhus": Walsh, op. cit., note 5 above, p. 16. He further refers to a "want of firmness and strength in the coats of the vessels, and of course in the solids at large" as a circumstance which will predispose to inflammation (p. 19). The explanation offered by John Leake for the origin of puerperal fever clearly linked inflammatory and solidist explanations of disease. He argued that "neither inanition nor plethora is natural to the body in a healthy state; ... the one extreme is as hurtful as the other, and will produce irritation in as high a degree; for in plethoric habits, where the vessels are overcharged, and violently upon the stretch, all the symptoms of irritability are evidently increased": Leake, op. cit., note 56 above, pp. 154-5. Another important insight into the link between inflammatory and vitalist explanations of puerperal fever is offered by Whitehead, who, in presenting a translation of a report by the French physician Doulcet, argued in one of his own footnotes that laxity of fibres - a typically solidist explanation-predisposed to inflammation, by allowing the pooling of blood in flaccid arteries: John Whitehead, A report made by order of government, of a memoir, containing a new ... method of treating the child-bed or puerperal fever, made use of by the late M. Doulcet, London, Frys and Couchman, 1783, ftn on pp. 23-4. 


\section{The Attempt to Understand Puerperal Fever}

John Alexander, writing in the 1830s, argued that puerperal fever was initially a disease of the abdominal nerves. ${ }^{107}$ It could, however, "merge" into an inflammatory condition depending on other circumstances present at the time. Hence, if the patient had been constipated, inflammation of the intestines might ensue. If she had undergone a difficult or damaging labour, the uterus might become inflamed, and if she had been exposed to cold, the peritoneum might have become affected. These inflammations were not, however, in themselves puerperal fever. ${ }^{108}$

\section{Theories of Putrefaction}

The idea of putrefaction was an important component of fever theory, and its extension was the notion of putrid effluvium, a subject explained by Kirkland and others in terms of the exhalation of the putrid matter into the air, and thence its conveyance to other individuals. ${ }^{109}$ The basic cause of the symptoms, predominant among which were weakness, debility and fever, was the effect of acrid matter in the body, which in eruptive fevers, or exanthemata, was expelled, in part onto the surface of the body, to cause the characteristic rash. ${ }^{110}$

The nature of putrefaction and of putrid effluvium was one that was given considerable attention by Matthew Dobson in his 1779 treatise, A medical commentary on fixed air. He describes putrefaction as:

the great process appointed by the CREATOR, for the resolution of animal and vegetable substances into the elements from which they were first formed. By this process, the oak and the bramble, the cedar and the hyssop, fruits whether delicious and nutritive, or acrid and poisonous, the most beautiful of the human species, and the most deformed of any of the other tribes of animals, are all reduced to one common lot. ${ }^{111}$

Hence, Dobson speaks of nature as something which does not necessarily favour mankind; it is, rather, an essentially rational, impersonal, impartial system, in which the bramble and the oak, the human being and the other animals will all meet the same fate-a dissolution or disintegration into particles which will then be reformed into new beings. This essentially materialist and fatalistic viewpoint - despite several references to the will of Godemphasizes that the system may work on its own without divine intervention.

The atomist theories which characterized this passage had throughout the early modern period been closely connected with atheism, and the dilemma for those scientists and philosophers who were interested in them-among them Descartes, Newton, Gassendi and Charleton-was whether there was a role for God in a mechanistic universe. This tension between natural philosophy and religion is still present in Dobson's writings, but Dobson is going beyond a purely mechanistic view of human functioning and adopting a more complex physiology, in which putrefaction is part of a vital process. ${ }^{12}$ The most important element of this theory was the observation that the breakdown of living matter

\footnotetext{
${ }^{107}$ John Alexander was Licentiate of the Royal College of Physicians and Medical Officer to the General Dispensary for Children during the 1830s.

${ }^{108}$ Alexander, op. cit., note 5 above, p. 16.

${ }^{109}$ Kirkland, op. cit., note 29 above; see also White and Butter, both cited in note 5 above.
}

\footnotetext{
${ }^{110}$ Kirkland, op. cit., note 29 above, esp. pp. 1, 13-27, 31-2.

${ }^{111}$ Matthew Dobson, A medical commentary on fixed air, London, printed for T Cadell, 1779, p. 74.

${ }^{112}$ Ibid., pp. 75-6; see also Fordyce, op. cit., note 6 above, pp. 15-18.
} 


\section{Christine Hallett}

into particles was a dangerous process. As these particles entered the air they became a potentially damaging substance known as "putrid effluvium".

A slightly more limited view was taken by William Fordyce, who saw putrefaction as a tendency possessed by some of the body fluids to a greater extent than others. Bile he saw as the fluid with the most dangerous putrefactive tendencies. ${ }^{113}$ The theory espoused by Denis Doulcet and reported by John Whitehead led to a belief that any cure that could remove putrid substances from the alimentary tract—such as ipecacuanha—was useful. ${ }^{114}$

In his preface to Albrecht von Haller's Dissertation on the sensible and irritable parts of animals, 1755, Samuel Tissot argued that most theories of fevers and inflammation drew upon ideas about the acridity and thus irritability of the blood. ${ }^{115}$ Putrid matter was frequently described as "acrid" by physicians, and hence could fulfil the role of irritant in the aetiology of puerperal fever. However, if acrid putrid matter caused inflammation which in turn led to the development of more pus - through the inflammatory process - the explanation of fever becomes cyclical, and the question remains: which comes first, inflammation or putrefaction?

Some writers still expressed ideas of putrefaction in terms borrowed from humoral theory. Henry Manning, for example, saw the disease as being essentially due to "putrid humours". His description of the process by which the disease became putrid was similar to the more directly inflammatory theories of contemporaries such as Denman, but he placed more emphasis on putrefaction as the basis of the disease. He argued for the importance of the vomiting and diarrhoea, suggesting that "the matter discharged by those evacuations is what chiefly foments the disease". 116 Similarly, writers such as White and Butter believed puerperal fever to be the result of poor lifestyle and "putrid effluvium" in the air. ${ }^{117}$ White explained puerperal fever as being caused by the absorption of acrid matter from the uterus. ${ }^{118} \mathrm{He}$ also referred to the infectious or contagious nature of the disease and hence has received more modern attention than some of the other treatise writers. ${ }^{119}$

The link between inflammation and putrefaction in the puerperal fever treatises is a difficult and somewhat complex one, and the impression is given that writers themselves were uncertain about how to draw this link. Denman provides a particularly interesting example of a writer whose perspective is developed over time-possibly as a result of reading the works of Hulme and Leake, as well as of his own increasing experience. In his Essays on the puerperal fever and on puerperal convulsions of 1768, he argued that

${ }^{113}$ Fordyce, op. cit., note 6 above, pp. 25-9.

${ }^{114}$ Whitehead, op. cit., note 106 above.

${ }^{115}$ Albrecht von Haller, A dissertation on the sensible and irritable parts of animals, Preface by S A D

Tissot, London, J Nourse, 1755, p. xxi.

${ }^{116}$ Manning, op. cit., note 5 above, p. 404.

${ }^{117}$ White, op. cit., note 5 above; Butter, op. cit., note 5 above, esp. pp. 4, 15-18. A member of the Corporation of Surgeons of London, Charles White was vice-president of the Literary and Philosophical Society of Manchester. He practised midwifery in Manchester for part of his career. William Butter was born in the Orkneys in 1726. He obtained his MD from
Edinburgh University in 1761 , and became a licentiate of the Royal College of Physicians of London and a Fellow of the Royal College of Physicians of Edinburgh.

${ }^{118}$ White, op. cit., note 5 above, p. 7. The inaugural dissertation of Patrick Keary discusses the putrid nature of the disease and cites the work of White: Patrick Keary, Dissertatio medica inauguralis, de febre puerperarum, Edinburgh, Balfour and Smellie, 1774.

${ }^{119}$ See, for example, J George Adami, Charles White of Manchester (1728-1813), and the arrest of puerperal fever, Liverpool University Press, 1922. 


\section{The Attempt to Understand Puerperal Fever}

puerperal fever began as an inflammatory condition, but progressed to a putrid disease after "some days". His evidence for this progression was a brown coating on the teeth, nausea, petecchiae and sometimes vesicular eruptions and diarrhoea. He added that "the stools are of such a nature as might be expected, and such as are always found in bilious and putrid diseases". ${ }^{120}$ In his later and much altered edition of this work, the Essays on the puerperal fever of 1773, Denman offered a more detailed description of this transition to putridity, commenting in particular on the nature of the stools, which become "very fetid, of a green or dark brown colour, and working like yeast". ${ }^{121}$

The concept of putrefaction was important to all writers on the subject of puerperal fever. Most saw it more as a consequence than as a cause of the fever. Inflammatory processes could lead to suppuration of organs and tissues, whilst debility and laxity of fibres could result in the retention of putrid fluids. ${ }^{122}$ White, however, saw puerperal fever as a disease which was fundamentally putrid. He related it to a number of factors affecting pregnancy, and argued that it could, in particular, be a consequence of prolonged constipation during pregnancy:

We must look back as far as the early months of pregnancy. At this period the tightness of the stays and petticoat bindings, the weight of the pockets and of the petticoats, press the womb, already enlarged by the foetus and its membranes, so strongly against the lower intestines as to prevent the descent and exclusion of the excrements.... This excrementitious matter being absorbed into the circulation undoubtedly occasions a great inclination to putridity. ${ }^{123}$

The process of putrefaction which thus begins early in pregnancy is continued at the time of delivery, by the "profuse sweats" which the woman experiences and which are encouraged by the fact that her chamber is deliberately maintained in a hot, airless state, by the exclusion of draughts, the presence of many birth attendants and the maintenance of a large fire. The heat and presence of many people's breath renders the air "foul and unfit for respiration", in a similar way to that in which the air of hospitals, jails and overcrowded accommodations is made unhealthy. The putrid fevers generated in such environments are almost invariably infectious. ${ }^{124}$

As soon as she is delivered, if she is a person in affluent circumstances, she is covered up close in bed with additional clothes, the curtains are drawn round the bed and pinned together, every crevice in the windows and door is stopped close, not excepting even the keyhole, the windows are guarded not only with shutters and curtains, but even with blankets, the more effectually to exclude the fresh air, and the good woman is not suffered to put her arm, or even her nose, out of bed, for fear of catching cold. ${ }^{125}$

Thus, White appears to believe that two sources of putrefaction fuel the puerperal fever. The first is the trapping of substances in the body which should normally escape, but which putrefy instead. The second is the air, which White appears to believe already contains substances which have a strong tendency to putrefaction, but which grows more dense and

\footnotetext{
${ }^{120}$ Denman, 1 st ed., 1768 , op. cit., note 5 above, pp. 11-12.

${ }^{121}$ Denman, 2nd ed., 1773, op. cit., note 5 above, pp. 12-13.

${ }^{122}$ Denman, 1 sted., 1768 , op. cit., note 5 above,p. 11.
} 


\section{Christine Hallett}

severe in overcrowded places, in places where there are already putrid wounds, and in "epidemical seasons". White thus comments that,

The lochia stagnating in the womb and in the folds of the vagina, soon grow putrid; for it is well known that the mildest humours in the human body, if suffered to stagnate, become so, as soon as the air has access to them. ${ }^{126}$

This same air is breathed and re-breathed by the woman to the further detriment of her health. Furthermore, the putrefaction of humours in her body is made worse because women are "generally of a lax, seldom of a rigid, fibre, owing in some measure to their periodical evacuations, to their sedentary, inactive, and domestic way of life, and likewise to their muscles being surrounded with a much larger quantity of cellular membrane than those of men". 127

Whilst the rich are affected by behaviours that will worsen their health, the poor are similarly affected, but by factors over which they have no control. If they live in cellars, their accommodation is overcrowded, damp and cold, and if in garrets, they are subject to human effluvia rising from lower floors and, in summer, to the heat of the sun on their roofs. Similarly, those who are obliged to enter lying-in hospitals will be subject to overcrowding and the unhealthy effluvia of other patients. ${ }^{128}$

White cites Denman and Leake in support of his view; both had previously referred to the movement around the body of putrid matter, sometimes occasioning abscesses. ${ }^{129}$ Maintaining the woman in a horizontal position in the post-partum period-as dictated by prevailing opinion at the time-causes more harm, by preventing the removal of putrid fluids and encouraging their further stagnation. It also makes it difficult to remove the placenta effectively. ${ }^{130}$ White concludes that puerperal fever "manifests itself to be of the putrid kind ... and is a malignant fever of the same genus as the jail or hospital fever". ${ }^{131}$

Butter witnessed what he described as an epidemic of puerperal fever in Derbyshire in the late 1770 s. His treatise was not taken very seriously either by later physicians, or by modern historians, who tended to view the fever he described as a form of gastroenteritis, rather than a "true" puerperal fever. The symptoms of those affected were predominantly gastrointestinal ones and the case fatality rate appears to have been remarkably-and unusually-low. Nevertheless, Butter's work forms an important part of the puerperal fever "corpus" of writings, presenting as it does a clear exposition of this disease as a "putrid" disorder. Butter argued that all fevers were essentially disorders of the "first passages", or alimentary canal. ${ }^{132}$ In common with White, he viewed constipation as an important predisposing cause, arguing that stools which were trapped in the body became putrid. It is for this reason that they were: "dark, slimy, clotty, very fetid, and often froth and ferment like barm: they always give relief to the patient; and are the only salutary crisis of the puerperal fever", 133

\footnotetext{
${ }^{126}$ Ibid., p. 207.

${ }^{127}$ Ibid., p. 207.

${ }^{128}$ Ibid., pp. 207-9.

${ }^{129}$ White, op. cit., note 16 above, pp. $18-27$.

${ }^{130}$ Ibid., p. 28; White, A treatise op. cit., note 95 above, pp. 262-3.
} 


\section{The Attempt to Understand Puerperal Fever}

Kirkland cited the English physician, John Pringle, and the French physician, Philippe Peu, in arguing that putrefaction of any kind, whether from women with puerperal fever or individuals with suppurating wounds, would lead to further cases of fever among those lodged nearby. He argued that "every fever [arises] from acrimony the consequence of its irritating the medullary part of the nerves" ${ }^{134}$ For this reason, hospitals could be dangerous places:

I have sometimes been called to women in childbed, where the offensive effluvia arising from this kind of evacuation, pent up in a small, close room, at once evinced to what cause their fever was owing. ${ }^{135}$

Whitehead, whose most famous contribution to eighteenth- and nineteenth-century theories of puerperal fever was his translation of the French physician, Doulcet's report on the use of ipecacuanha, viewed puerperal fever as a disease which could be either inflammatory or putrid, but which frequently took the latter form. ${ }^{136} \mathrm{He}$ observed that "the more the putrid character prevails, the more rapid and dangerous the disease appears in general". ${ }^{137} \mathrm{He}$ offered the following classic description:

The putrid Puerperal Fever has all the essential characters of the Putrid Fever, the Typhus of Dr Cullen. The heat is not violent; the pulse is small, weak and quick; there is a sudden and great prostration of strength; and the matters evacuated are highly foetid ... This disease, like the Putrid Fever, is often epidemic and contagious; it is most frequent and fatal in hospitals, in close confined and crowded situations where the air is foul; it is increased by every thing which tends to generate a putrid miasma, from which I think we may conclude, that it is, in its essential character, a Putrid Fever. $^{138}$

A number of early-nineteenth-century authors observed that it was important not to neglect the putrid characteristics of puerperal fever and the contagious effects that could result from these. Among them was John Burns, who argued that, "The disease appears to depend on inflammation of the peritoneum, conjoined with the operation of some debilitating poison, probably, in most cases, more or less contagious". ${ }^{139}$ Burns pointed out that, in his view, it was important to distinguish puerperal fever from peritonitis, a much more obviously inflammatory condition. In puerperal fever, the patient's symptoms were characterized more by debility, betraying the more "nervous" nature of the disease. ${ }^{140}$

\footnotetext{
${ }^{134}$ Kirkland, op. cit., note 29 above, p. 31.

${ }^{135}$ Kirkland, op. cit., note 80 above, p. 293; see also pp. 293-97. For an example of a case explained by putrid effluvium, see Churchill (ed.), ibid., p. 298.

${ }^{136}$ John Whitehead was born in Lancashire. He obtained his MD from Leyden in 1780. He became a licentiate of the Royal College of Physicians of London in 1782 .

${ }^{137}$ Whitehead, op. cit., note 106 above, p. 32.

${ }^{138}$ Ibid., p. 24.
}

\footnotetext{
${ }^{139}$ Burns, op. cit., note 79 above, p. 428.

${ }^{140}$ Ibid., p. 428. The French physician, Baudelocque, argued for the influence of a number of factors that had come to be seen as causative elements in the process of putrefaction: poor quality food, alcohol, constipation, "impure matter" in the alimentary canal, retention of the urine, and "impurity" of the atmosphere: Baudelocque, op. cit., note 5 above, pp. 64-8, 96-8, 112-153.
} 


\section{Christine Hallett}

\section{Nineteenth-Century Inflammation Theorists}

In spite of the arguments of putrefactionists, inflammatory theory became entrenched in the work of the nineteenth-century physicians. John Armstrong, in 1814, viewed puerperal fever as a "local inflammation" detectable via morbid anatomy, ${ }^{141}$ and William Hey, writing in 1815, agreed with this analysis, commenting that he and Armstrong had both independently reached the same conclusion. ${ }^{142}$ Such a comment is interesting, given the emphasis on inflammation throughout the eighteenth and early nineteenth centuries. It is clear that very few of these authors were reaching independent conclusions. Rather, all were probably heavily influenced by the earlier works of the 1760 s and 1770 s and by eighteenth-century fever theory more generally. ${ }^{143}$

The early-nineteenth-century Edinburgh physician, William Campbell, was particularly insistent upon the inflammatory nature of puerperal fever, and appears, like Hey and Armstrong, to have been strongly influenced by the work of Gordon. Citing extensive evidence from his own cases and dissections, he pointed to a number of symptoms and signs which, he argued, must be seen as indications of inflammation, namely "rigors, quick, firm corded pulse, acute fixed pain, tumefaction and increased heat", ${ }^{144}$ and a number of findings on dissection-increased vascularity, excitement, suppuration and gangrene, with the effusion of serum and coagulable lymph — which were also highly indicative of inflammation. ${ }^{145} \mathrm{He}$ added, furthermore, that those who had treated puerperal fever as an inflammatory affection, and had used methods of depletion, such as bleeding and purging, had had better success rates than others. ${ }^{146}$

Published in the same year as Campbell's treatise was that of John Mackintosh, who commented on the consensus among authors of his own day that puerperal fever was inflammatory, though its nature was still open to debate: it was seen as either a simple inflammation of the uterus, a peritonitis, or as a "peculiar idiopathic fever". ${ }^{147}$ He added that physicians could be divided into three groups in respect of their treatment of puerperal fever:

Those who treat it as an inflammatory disease.

Those who consider it as an inflammatory disease, but dread to use the only effectual means of cure.

And, lastly,

Those who consider it as a peculiar disease attending childbed—of a low, typhoid, or malignant form, and treat it accordingly with stimulants. ${ }^{148}$

Robert Gooch argued that puerperal fever was so clearly a disorder of the peritoneum that it should more accurately be named "peritoneal fever". He added, however, that the affection

\footnotetext{
${ }^{141}$ Armstrong, op. cit., note 5 above, p. viii; on the inflammatory nature of the disease, see Preface, esp. pp. vii-viii, and pp. 14-22; on the contagious nature of puerperal fever, see pp. 12, 33-4.

${ }^{142}$ Hey, op. cit., note 13 above, Preface. William Hey was surgeon to both the General Infirmary and the House of Recovery in Leeds.

${ }^{143}$ It is likely that Hey and Armstrong were particularly heavily influenced by those of their predecessors who had emphasized what they saw
}

as an inflammatory nature to puerperal fever: among others, Leake, Hulme, and most particularly, Gordon. Leake, Practical observations, op. cit., note 27 above; Hulme and Gordon both cited in note 5 above.

${ }^{144}$ Campbell, op. cit., note 5 above, p. 172.

${ }^{145}$ Ibid., pp. 172-3.

${ }^{146}$ Ibid., p. 175.

${ }^{147}$ Mackintosh, op. cit., note 11 above, pp. 1-2.

${ }^{148}$ Ibid. p. 5. 


\section{The Attempt to Understand Puerperal Fever}

of the peritoneum, whilst often inflammatory in nature, was not invariably so. ${ }^{149}$ In common with Gordon, Hey and Armstrong, Gooch emphasized the need to bleed and purge the patient early in order to treat the inflammation before the effusion set in-by which time it would be too late to treat with any confidence of success. ${ }^{150}$ George Moore observed, similarly, that an increasing interest in morbid anatomy had strengthened the view that puerperal fever was inflammatory in nature, by revealing the signs of inflammation-disorganization of tissues, "increased vascular action", and the pooling of blood. ${ }^{151}$

A number of nineteenth-century writers-notably Campbell, Cusack and Lee-agreed with Gooch that the term "peritonitis" might be used in place of "puerperal fever" or "childbed fever". ${ }^{152}$ Campbell deplored the use of the term "low malignant childbed fever", arguing that it was "contrary to common sense". Rather than being a "low" fever, this was "a disorder of a highly inflammatory character". Terming it "low" and "malignant" could damage the honour of the profession, because it only took on these characteristics in the long term if the initial inflammation was neglected. ${ }^{153}$

Lee stated that "inflammation of the uterus and its appendages must be considered as essentially the cause of all the destructive febrile affections which follow parturition". 154 He proposed four basic types of this disorder, all of which were defined in terms of anatomical structure:

$1^{\text {st }}$. Inflammation of the peritoneal covering of the uterus, and of the general peritoneal sac.

$2^{\mathrm{dly}}$. Inflammation of the uterine appendages; ovaria, Fallopian tubes, and broad ligaments.

$3^{\mathrm{dly}}$. Inflammation of the muscular or proper tissue of the uterus.

$4^{\text {thly }}$. Inflammation and suppuration of the veins, and absorbent vessels of these organs. ${ }^{155}$

He differed from Gooch and Campbell in stating that puerperal peritonitis was only one variety of puerperal fever; yet he did give puerperal peritonitis an important role in his schema, arguing that this form of fever was very similar to peritonitis in men. ${ }^{156}$ The

\footnotetext{
${ }^{149}$ Gooch, op. cit., note 5 above, pp. 2, 62. Robert Gooch was born in Yarmouth in 1784. He obtained his MD from Edinburgh University in 1807, and was a licentiate of the Royal College of Physicians. He was physician to the Lying-in Hospitals of London and Westminster during the 1820s, and later became physician to the City of London Lying-in Hospital. He lectured on midwifery at St Bartholomew's Hospital. He died in 1830. Irvine Loudon has suggested that Fleetwood Churchill in his treatise of 1849 was the first to propose the name "puerperal peritonitis". Loudon, op. cit., note 1 above, p. 8.

${ }^{150}$ Gooch, ibid., pp. $62-3$. The same view is expressed by Campbell, op. cit., note 5 above, p. 11 .

${ }_{151}^{15}$ Moore, op. cit., note 10 above, pp. 74, 93-4.

${ }^{152}$ William Campbell was physician to the Edinburgh Infirmary. Samuel Cusack was a member of the Royal College of Surgeons in Ireland. He was "Superintending Accoucheur" to the Wellesley Dispensary for Lying-in Females on Mercer Street, in
}

Dublin. Robert Lee was born in Melrose, Roxburghshire in 1793. He obtained his MD from Edinburgh in 1814 and became a licentiate of the Royal College of Physicians in 1823. He became physician to the British Lying-in Hospital in 1826, Regius Professor of Midwifery to the University of Glasgow in 1834, Professor of Midwifery at St George's Hospital later the same year, and Fellow of the Royal College of Physicians in 1841.

${ }^{153}$ Campbell, op. cit., note 5 above, pp. 191-4; Cusack, op. cit., note 6 above, pp. 2-5. For further discussion of Cusack's view, see Samuel Cusack, 'On puerperal fever-letter from Dr. Samuel Cusack to the editors', Dublin Journal of Medical Science, 1836, 9: $162-5$. On the inflammatory nature of puerperal fever, see also Ryan, op. cit. note 10 above, esp. p. 330.

${ }^{154}$ Lee, Pathological and practical researches, op. cit., note 73 above, p. 2.

${ }^{155}$ Ibid., p. 4.

${ }^{156}$ Ibid., pp. 4-6. 


\section{Christine Hallett}

anatomical element in these debates - the emphasis on locating the origin and the seat of the inflammation-is a central element in the work of the early-nineteenth-century physicians.

By 1839, Ferguson was arguing that puerperal fever could take any one of four forms, all of which were components of a single disease process linked to "vitiation of the fluids", but each of which could appear independently. The first was an inflammatory form, which was characterized mainly by peritonitis; the second a "common fever"; the third a fever affecting the brain and nervous system; and the fourth a "complicated" type. The first form could be further subdivided into two types - the "transient" and the "permanent". The latter was a very serious, intractable and dangerous disease with four distinct stages. In the first stage there was "shivering, a hot and a sweating fit, lasting from one hour and a half to six hours" and accompanied by "much agitation of mind". The second stage was characterized by "abdominal pain, fever, general turgor, hard, frequent and compressed pulse, supine posture, and restrained breathing". The third stage was "that of effusion, marked by apparent amelioration in all the symptoms", and the fourth was "that of collapse, in which the countenance is changed, the respiration laborious; the surface cool, clammy, and slightly livid; the abdomen swollen; the pulse too frequent to be counted; the mind usually perfectly clear". ${ }^{157}$

\section{Conclusion}

The debate about whether puerperal fever was essentially inflammatory or essentially putrid found its way, in some form, into most of the late-eighteenth- and early-nineteenthcentury works on this subject. This debate reflected a wider nosological one about whether "putrid" could be seen as a separate category of fevers at all—or merely as a part of the progress of fevers generally. William Cullen argued, in his First lines of the practice of physic, that both ancient and modern writers had tended to divide fevers into "putrid" and "non-putrid". He suggested that they had been mistaken in doing so. Fluids did, in his view, become putrid during fevers, but this tended to happen in all types of fever and could not, therefore, be seen as a truly distinguishing characteristic:

This putrescency ... often attends intermittent, as well as continued fevers, and, of the continued kind, both the synochus and typhus, and all of them in very different degrees; so that, whatever

\footnotetext{
${ }^{157}$ Ferguson, op. cit., note 23 above. For an introduction to the schema, see pp. 1-2. The direct quotations are taken from $\mathrm{p}$. 21. In discussing his other "forms" of puerperal fever, Ferguson, in common with other late-eighteenth- and early-nineteenth-century writers, identified the inflammation as being of an "erysipelatous" form: ibid., p. 28. Ferguson included one case study — number XXXIII—with the clear purpose of illustrating this link between puerperal fever and erysipelas. Lucy Roberts had symptoms of puerperal fever, accompanied by an "erysipelatous blush ... on the right hip". The erysipelas spread to the limbs and an abscess broke out on the arm. The patient
}

recovered, but only after several weeks. Ibid., pp. 168-75. On the erysipelatous nature of puerperal fever, see also Gordon, op. cit, see note 5 above, p. 55. Also George Weatherhead, An essay on the diagnosis between erysipelas, phlegmon and erythema, London, Longman, Hurst, Rees, Orme and Brown, 1819, pp. 14-18; Moore, op. cit., note 10 above, pp. 142-8; and Lee, Pathological and practical researches, op. cit., note 73 above, p. 66. Lee cites other authors who argue that puerperal fever represents erysipelas, among them Pouteau, Home, and Young of Edinburgh, Gordon, Pinel, Bayle, Garsc and Laënnec, see pp. 66-70. 


\section{The Attempt to Understand Puerperal Fever}

attention it may deserve in practice, there is no fixing such limits to it as to admit of establishing a species under the title of putrid. ${ }^{158}$

The focus on inflammatory and putrid processes and the controversy about which was the more important mark this period out as one characterized by uncertainty. One, indeed, which could be seen in Thomas Kuhn's terms as a "pre-paradigm era". ${ }^{159}$

Towards the end of the period under consideration here, two physicians, one in the United States of America and one in Hungary, produced work that was later to be regarded as seminal in the understanding of what is now seen as the infectious nature of puerperal fever. In 1843, Oliver Wendell Holmes published 'The contagiousness of puerperal fever' in the New England Quarterly Journal of Medicine and Surgery, ${ }^{160}$ and in 1860 Ignaz Semmelweis published work, which he had first embarked on about fifteen years earlier, as The etiology, concept and prophylaxis of childbed fever. ${ }^{161}$ In 1850 , at the very end of the period under study here, James Young Simpson contributed further to the understanding of the infectious nature of this disease, by recognizing its similarities to "surgical fever". ${ }^{162}$ These writers have not been given prominence in the present paper, partly because their writings do not appear to have been given great attention by their own contemporaries. Although they may have been received with interest, particularly during the later part of the period, when there was a growing recognition that puerperal fever could be transmitted by birth attendants, their theories formed only one, rather marginal element within contemporary writings. Far greater emphasis appears to have been given to theories of the origin of the fever itself, which was seen as a constitutional disorder, most commonly arising from within the organism and only rarely invading from outside.

There were some serious attempts at consensus during the first half of the nineteenth century about what the origins of this particular fever might be. The most striking of these was Robert Ferguson's 1839 treatise, Essays on the most important diseases of women. ${ }^{163}$ Ferguson's elaborate presentation of four puerperal fever types was not the first attempt to summarize and encapsulate all prevailing theories in one schema. It was, however, by far the most intricate, complex and advanced. The problem with attempts at "overview" such as this one was that they merely "bolted together" a range of often-conflicting theories and ideologies, rather than presenting a coherent perspective. They were to be swept away in the last decades of the nineteenth century-made obsolete by germ theory.

Perhaps, then, the real significance of the puerperal fever treatises of the late eighteenth and early nineteenth centuries lies in the glimpse they can offer into medical perception and

\footnotetext{
${ }^{158}$ Cullen, op. cit., note 43 above, pp. 63-4.

${ }^{159}$ Thomas S Kuhn, The structure of scientific revolutions, 3rd ed., University of Chicago Press, 1996, pp. 178-9.

${ }^{160}$ Oliver W Holmes, 'The contagiousness of puerperal fever', Medical Classics, 1937-37, 1: 211-43, reprinted from the N. England Q. J Med. Surg., 1843, 1 (4): 503-30; idem, 'Puerperal fever as a private pestilence', Medical Classics, 1936-37, 1: $211-68$.

${ }^{161}$ I Semmelweis, The etiology, concept and prophylaxis of childbed fever, transl. K Codell Carter, Madison, University of Wisconsin Press, 1983.
}

\footnotetext{
${ }^{162}$ James Young Simpson, 'On the analogy between puerperal fever and surgical fever', Edinb. mon. J. med. Sci., Nov. 1850: 414. See also James Young Simpson, 'On the communicability and propagation of puerperal fever', Proceedings of the Medico-Chirurgical Society, April 1851, reprinted in the Edinb. mon. J. med. Sci., July 1851: 72. Both reprinted in the Obstetric memoirs and contributions of James Y Simpson, Edinburgh, A \& C Black, 1855-56.

${ }^{163}$ Ferguson, op. cit., note 23 above, Part I. Puerperal fever.
} 


\section{Christine Hallett}

scientific theory-building. Not only was the nature of puerperal fever highly contested by inflammationists and putrefactionists, but this was a "high-stakes" contest. The bleeding and purging of the inflammationists was seen by putrefactionists to worsen the debility of the patient, whilst the failure to bleed the patient on the part of the putrefactionists was seen as neglect by the inflammationists. Uncertainty and conflict thus prevailed; they were not to be resolved until the reception of "germ theory" towards the end of the nineteenth century. 